\title{
Diversity of Demographic Characteristics and Work Performance in Nepalese Banking Industry
}

\author{
Dr. Prakash Shrestha \\ Lecturer, Nepal Commerce Campus, Tribhuvan University, Nepal \\ Asso. Prof. Dr. Dilip Parajuli* \\ Bhaktapur Multiple Campus, Tribhuvan University, Nepal
}

\begin{abstract}
Nepal is ethnically heterogeneous and is characterized by several workplace-reflective diversities. This paper established the relationship between the diversity of demographic characteristics and the performance of employees in the Nepalese banking industry. A structured questionnaire was used as a tool of the survey among the employees of three commercial banks of Nepal and 61.11 percent of responses were received and use for data analysis purposes. The results indicate that diversity of demographic characteristics in terms of ethnic diversity, education diversity, age diversity, and gender diversity have a strong and positive relationship with work performance. The results of this study can be used to build strategies for optimizing the implementation of the diversity of demographic characteristics of employees in their work performance.
\end{abstract}

Keywords: Demographic characteristics, Diversity, Ethnicity, Education, Age, Gender, Performance

DOI: $10.7176 / \mathrm{EJBM} / 12-36-01$

Publication date: December $31^{\text {st }} 2020$

\section{Introduction}

The concept of diversity is becoming a part of corporate practices in the business sector, as women and minorities join the workforce at a growing pace. In addition to questions of moral, ethical, and legal enforcement, several businesses have made the strategic decision to invest in a diverse workforce seeking to boost efficiency and keep a competitive advantage (Erhardt, 2003). Workforce diversity is the condition that occurs when, in terms of demographic factors such as age, sex, race, ethnicity, immigration, and education, members of a group or organization vary from each other. A broad range of elements has produced a much more diversified workforce, such as an aging population, involvement of women and minorities in employment, globalization, knowledgebased people, contractual employees, online jobs.

Nepal is a country with a multi-ethnic and multi-lingual community. People of different religions, cultural backgrounds, castes, ethnic groups, languages are found in Nepalese workplaces. Hence, the diversity of the workforce is also quite remarkable in Nepal. This issue is how well such diversity can be managed by companies. The banking industry is a rapidly growing industry (Shrestha, 2018, 2019). There have been many challenges posed by rapid growth in the banking sector, such as the diversity of the workforce.

The magnitude of diversity in organizations can all lead to equal employment opportunities laws, organizational efforts driven by business necessity, and labor market trends (Jackson \& Alvarez, 1992, Joshi, 2006). Usually, the early concept of diversity included demographic parameters such as gender and workplace ethnicity (Ashkanasy, Hartel, \& Dass, 2002). Two general distinctions between observable and non-observable diversity features arose as organizational diversity research advanced (Erhardt, 2003). The first one is visible features (also called surface-level diversity) that include gender, age, race, and ethnicity. Such features are usually categorized as measurable diversity. The next one is the non-observable characteristics (also known as deep-level diversity). They include knowledge, education, beliefs, cognition, affection, and personality (Pelled, 1996; Milliken \& Martins, 1996; Boeker, 1997; Watson, Johnson, \& Merritt, 1998; Harrison, Price, \& Bell, 1998; Kilduff, Angelmar, \& Mehra, 2000; Østergaard, Timmermans, \& Kristinsson, 2011). However, this study is concerned with the diversity of demographic characteristics in terms of ethnicity, education, age, and gender diversity.

As the workplace continues to diversify, there is growing research on diversity and its effect on and work performance. In a study, Choi (2007) reported that diversity leads to synergistic effects when organizational members can understand and appreciate each other and draw on each other's experiences, talents, and perspectives. Organizations that consider diversity as part of their key strategy rather than a business expense will benefit much more than the organization that does not (Brown, 2008). Some studies have shown that great creativity, increased strategic decision-making, and organizational performance have been associated with different types of diversity domains. Other research indicates that conflict is often exacerbated by different forms of organizational diversity, social stability is decreased and employee turnover is exacerbated (Kochan et al., 2003). The demographic composition of today's workplace is becoming increasingly diverse (Omankhanlen \& Ogaga-oghene, 2011). Business organizations are therefore facing the difficulties of handling a diverse workforce effectively. The Nepalese banking industry is also facing the same challenges due to workforce diversity. However, workforce 
diversity offers many benefits to this industry. One of the key benefits would be the higher level of work performance. Hence, this study establishes the relationship between the diversity of demographic characteristics and work performance considering the banking industry of Nepal.

\section{Conceptual Background and Hypothesis Formulation}

Nepal is ethnically heterogeneous, like many other nations in the world, and is distinguished by a range of workplace-reflective diversities (SIAG, 2008). Diversity refers to the distribution among interdependent members of a work unit of personal attributes (Erhardt, 2003). It is constantly recognized and used as an important organizational resource to provide excellent customer support or to maintain a competitive advantage (Kyalo \& Gachunga, 2015). According to Jackson, May, and Whitney (1995), the existence of differences between members of a social unit can be characterized as diversity. Shaw and Barrett-Power (1998) reported that as organizations around the world become more diverse in terms of their members' gender, race, ethnicity, age, national origin, and other personal characteristics, diversity is an increasingly significant factor in organizational life. Many previous studies (e.g., Rosen and Lovelace, 1991; Deluca \& McDowell, 1992; Morrison, 1992) reported that the workforce today includes individuals that are distinct and share various attitudes, needs, expectations, beliefs, and behaviors of work. Emiko and Eunmi (2009) observed that workforce diversity increases the efficiency of employees and organizations. Among other variables, diversity based on some demographic characteristics such as ethnicity, education, gender, and age can affect positions, relationships, and performance of the employees (Omankhanlen \& Ogaga-oghene (2011).

\subsection{Relationship between Diversity of Demographic Characteristics and Work Performance}

Diversity of demographic characteristics of the workforce as a resource seeks to identify, respect, and appreciate the advantages that heterogeneous workers can bring to improving company efficiency (Rasul \& Rogger, 2015). It is important for enhancing work performance. Performance implies the action of doing; identifiable and observable duties, achievement, or accomplishment in the performance of duty. Work performance refers to the successful discharge of one's obligation to obtain results. It is nothing more than how well an employee meets the job's specifications (Rue and Byars, 1993). Workforce diversity is positively linked to creativity, growth, innovation, and critical thinking skills, according to Milliken and Martins (1996), Jehn, Northcraft, and Neale (1999). It is expected that good workforce diversity practices can enhance and increase employee and organizational efficiency (Adler, 1986). Since the performance of an individual employee is categorically influenced by organizational performance, the positive influences of workforce diversity at the employee level will help to improve employee cooperation (Kumar \& Suresh, 2018). Fernandez (1993) argues that effective management of workforce diversity can increase the performance of employees. This is because diversity management means exploiting and using the discrepancies between the talents, concepts, and ingenuity of the employee to contribute to the accomplishment of the shared objective and to do so in a way that gives the company a competitive advantage. These kinds of literature support that there is a positive relationship between workforce diversity and work performance.

\subsection{Diversity of Demographic Characteristics}

Mainly, demographic characteristics such as ethnicity, education, gender, and age are considered in this study. Ethnic Diversity

Ethnic diversity is a condition in which people from several cultural and national backgrounds are present in the area. Ethnicity is an ethnicity linked to a particular national or cultural tradition. Ethnic diversity, then, refers to various ethnic groups or cultures being present. In Nepal, many individuals identify with more than one ethnic group. This, too, is thrilling as well as difficult ways that will affect their psychological makeup and well-being. It also affects the performance of employees in the workplace. Some previous studies of Weiliang et al. (2011) and Early and Mosakowski (2000) have reported that there is a significant relationship between ethnic diversity and work performance. Based on these discussions, the following hypothesis emerged:

\section{Education Diversity}

H1. A strong and positive relationship exists between ethnic diversity and work performance.

The background of education is important to the level of employability of employees. Without proper educational history, employees cannot find a job and perform well (Kyalo \& Gachunga, 2015). Generally, employers also employ employees whose education, training, and experience are sufficient for employment. Glaeser, Scheinkman, and Shleifer (1995) estimated that higher levels of education among employees would contribute to higher economic growth. Benschop (2001) argued that cities with a higher percentage of employees at the tertiary education level would encourage people at all levels of education to secure higher salaries. Similarly, Daniel (2009) stated that the increased level of education could increase employee mobility rates. Thus, the performance of the individual employee would be more due to their more qualification (Kumar \& Suresh, 2018). Based on these discussions, the following hypothesis emerged: 
H2. A strong and positive relationship exists between education diversity and work performance.

\section{Age Diversity}

Growing age diversity has become one of a modern organization's key features. Some previous studies by Williams \& O'Reilly III (1998) and Wegge et al. (2008) reported that age diversity has a positive influence on the organization and work performance. It is argued that a heterogeneous age group of workers will be more imaginative, diverse, and profitable than a homogeneous age group. Considering the above discussions, the following hypothesis is proposed:

\section{Gender Diversity}

H3. A strong and positive relationship exists between age diversity and work performance.

One of the main factors affecting work performance positively or negatively is gender diversity. Gender can be either femininity or masculinity. In the workplace, gender-based diversity creates greater individual performance. Many research studies support this argument. From the resource-based view that gender diversity gives a company a competitive advantage, McMillan-Capehart (2003) observed. Besides, according to Kochan et al. (2003), it is important to provide women with equal employment opportunities to increase the performance of employees in an organization. Based on these discussions, the following hypothesis emerged:

H4. A strong and positive relationship exists between gender diversity and work performance.

\section{Methodology}

This study adopts a descriptive research design that explains descriptions of the diversity of demographic characteristics and work performance in the Nepalese banking industry. A total of 180 structured questionnaires were distributed to employees of three commercial banks (namely, Nepal Bank Limited, Prabhu Bank Limited, and Sunrise Bank Limited). Only 61.11 percent of useful questionnaires were received and use for data analysis purposes. Demographic characteristics of the respondents are presented in the following table:

Table 1: Demographic characteristics of respondents $(n=110)$

\begin{tabular}{lcc}
\hline Respondents character & No. of responses & Percentage \\
\hline Ethnicity & 29 & \\
Brahmin & 31 & 26.36 \\
Chettri & 38 & 28.18 \\
Janajati & 12 & 34.55 \\
Others & & 10.91 \\
\hline Education & 1 & \\
Ph. D & 5 & 0.9 \\
M.Phil. & 58 & 4.5 \\
Master & 43 & 52.3 \\
Bachelor & 4 & 38.7 \\
+2 & & 3.6 \\
\hline Age (years) & 2 & \\
Up to 20 & 64 & 1.82 \\
21-30 & 37 & 58.2 \\
31-40 & 6 & 33.6 \\
$41-50$ & 1 & 5.45 \\
Above 50 & & 0.91 \\
\hline Gender & 57 & 51.82 \\
Male & 53 & 48.18 \\
Female & 5 & 1 \\
\hline
\end{tabular}

The questionnaire is measured using a 5-point Likert scale, ranging from one (strongly disagree) to five (strongly agree). Descriptive statistics are used, including mean and standard deviation (S.D.), as methods of data analysis. The correlation analysis is carried out to establish a relationship between the diversity of demographic characteristics and work performance. The relationship is presented in the following research framework.

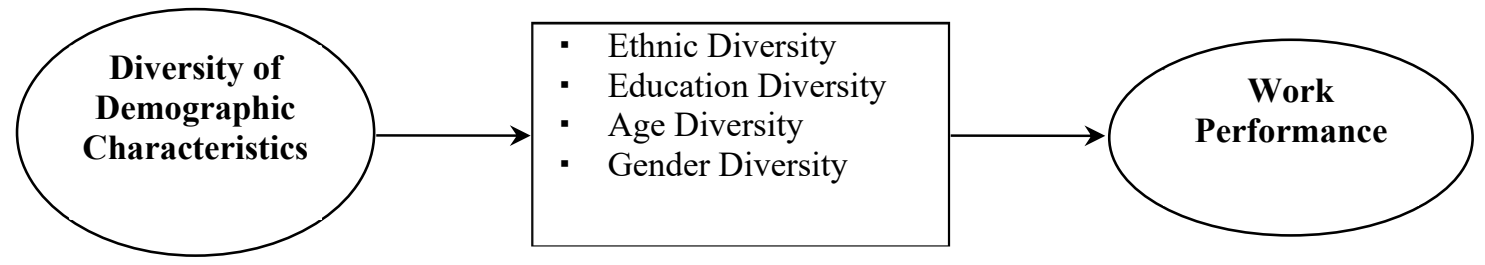

Figure 1. Diversity of Demographic Characteristics and Work Performance 


\section{Data Analysis and Findings}

\subsection{Ethnic Diversity}

Table (2) shows the level of agreement on various statements concerning ethnic diversity and work performance in their organization.

Table 2: Ethnic Diversity

\begin{tabular}{clcc}
\hline S.N. & \multicolumn{1}{c}{ Statement } & M & S.D \\
\hline 1. & $\begin{array}{l}\text { Different languages used to communicate in the workplace does not create conflict } \\
\text { among employees }\end{array}$ & 3.56 & 1.03 \\
\hline 2. & $\begin{array}{l}\text { My ethnic background and my working with colleagues from different ethnic } \\
\text { background influences my ability to carry out my task well }\end{array}$ & 2.16 & 1.22 \\
\hline 3. & I cooperate well with my colleagues of different ethnicity & 3.94 & 1.15 \\
\hline 4. & I develop low self-esteem in the workplace due to my ethnic background & 2.13 & 1.11 \\
\hline 5. & The language differences among employees affect group formation and cohesion & 3.43 & 1.16 \\
\hline
\end{tabular}

The results show that employees cooperate well with their colleagues of different ethnicity. They feel that different languages used to communicate in the workplace do not create conflict among the employees. Additionally, they also agree that language differences among the employees affect group formation and cohesion. Further, results reveal that their ethnic background and their working with colleagues from different ethnic backgrounds influence their ability to carry out their tasks well. However, the employees feel that they develop low self-esteem in the workplace due to their ethnic background.

\subsection{Education Diversity}

Table (3) shows the level of agreement on various statements about education diversity and work performance in their organization.

Table 3: Education Diversity

\begin{tabular}{clcc}
\hline S.N. & \multicolumn{1}{c}{ Statement } & M & S.D \\
\hline 1. & Qualification is a discriminatory factor in the organization. & 3.86 & 0.81 \\
\hline 2. & $\begin{array}{l}\text { The recruitment plan of the organization is based on the educational background of } \\
\text { employees. }\end{array}$ & 3.91 & 0.78 \\
\hline 3. & My educational level affects my ability to perform my core task responsibility & 3.44 & 1.62 \\
\hline 4. & The difference in the educational background does not encourage conflict. & 3.61 & 0.38 \\
\hline 5. & At work, I experience a lack of confidence due to my educational background. & 3.23 & 1.61 \\
\hline
\end{tabular}

The findings reveal that employees feel that the recruitment plan of the organization is based on their education diversity. They also agree the qualification is a discriminatory factor in the organization. Additionally, the difference in the educational background does not encourage conflict. The results also reveal that employees' educational level affects their ability to perform their task responsibility. Besides, they experience a lack of confidence due to their educational background.

\subsection{Age Diversity}

Table (4) shows the level of agreement on various statements with age diversity and work performance in their organization.

Table 4: Age Diversity

\begin{tabular}{llcc}
\hline S.N. & \multicolumn{1}{c}{ Statement } & M & S.D \\
\hline 1. & $\begin{array}{l}\text { The expertise of young employees with high-tech tools helps older employees to } \\
\text { improve their knowledge of the latest technologies. }\end{array}$ & 4.23 & 0.81 \\
\hline 2. & The mentoring by older employees benefited young employees in acquiring job skills & 3.97 & 0.61 \\
\hline 3. & $\begin{array}{l}\text { My team members include all members of different ages in problem-solving and } \\
\text { decision-making. }\end{array}$ & 3.92 & 0.82 \\
\hline 4. & The age difference in the workgroup might cause conflict. & 3.23 & 0.41 \\
\hline 5. & I did not experience stress in the last 12 months due to age diversity in my workplace. & 3.65 & 0.77 \\
\hline
\end{tabular}

These results show that the expertise of high-tech and knowledge-based workers helps senior workforces develop their knowledge of recent technologies and techniques. The mentoring by older employees get benefited young employees in getting job skills. Further, team-members of different ages support problem-solving and decision-making processes. Even though there is a possibility of conflict, but the employees did not experience stress in the last 12 months due to the age diversity in their workplace. 


\subsection{Gender Diversity}

Table (5) shows the level of agreement on various statements in terms of gender diversity and work performance in their organization.

\section{Table 5: Gender Diversity}

\begin{tabular}{llcc}
\hline S.N. & \multicolumn{1}{c}{ Statement } & M & S.D \\
\hline 1. & $\begin{array}{l}\text { The employee has not been discriminated against by the employer while the hiring and } \\
\text { recruitment process on a gender basis. }\end{array}$ & 3.86 & 0.39 \\
\hline 2. & $\begin{array}{l}\text { Gender diverse team showed better problem solving and decision-making skills than } \\
\text { gender homogeneous teams. }\end{array}$ & 3.73 & 0.49 \\
\hline 3. & Fair treatment is given to all employees, whether they are male or female & 3.97 & 0.57 \\
\hline 4. & Opportunities for growth and advancement exist for the woman in the organization. & 3.84 & 0.67 \\
\hline 5. & $\begin{array}{l}\text { I did not experience stress in the last 12 months due to gender diversity issues in my } \\
\text { workplace. }\end{array}$ & 3.64 & 0.83 \\
\hline
\end{tabular}

The results reveal that there is a fair treatment to all employees whether they are male or female. The employees agree that they have not been discriminated against by the employer while hiring and recruitment processes on a gender basis. There are opportunities and advancement possibilities for the woman in the organization. Additionally, gender diverse team has better problem solving and decision-making skills than gender homogeneous team. Further, the employees did not experience stress in the last 12 months due to the gender diversity issues in their workplace.

\subsection{Work Performance}

Table (6) shows the level of agreement on various statements in terms of work performance in their organization.

Table 6: Work Performance

\begin{tabular}{llcc}
\hline S.N. & \multicolumn{1}{c}{ Statement } & M & S.D \\
\hline 1. & I enjoy my tasks and the division's work approach. & 4.27 & 0.51 \\
\hline 2. & I cooperate well with my colleagues of different ethnicity. & 4.12 & 0.91 \\
\hline 3. & Opposite gender can perform well and I enjoy working with them. & 3.95 & 0.82 \\
\hline 4. & By learning more skills through courses/training, I can improve my task performance. & 4.22 & 0.63 \\
\hline 5. & Good work performance is important for the further growth of my organization. & 4.29 & 0.52 \\
\hline
\end{tabular}

The results indicate that good employees' performance is important for the further growth of their organization. The employees enjoy their tasks and the division's work approach. Further, they feel that by learning more skills through courses or training, they can improve their task performance. They cooperate well with their colleagues from different ethnicity. They also perceive that the opposite gender can perform well and they enjoy working with them. The results indicate that workforce diversity affects work performance.

\subsection{Correlation Analysis}

The findings and discussions of the correlation analysis are presented in the following table.

Table 7: Correlation between the Dependent and the Independent Variables

\begin{tabular}{lccccc}
\hline \multicolumn{1}{c}{ Study Variables } & A & B & C & D & E \\
\hline Work Performance (A) & 1 & & & & \\
\hline Ethnic Diversity (B) & $0.72^{* *}$ & 1 & & & \\
\hline Education Diversity (C) & $0.81^{* *}$ & $0.57^{*}$ & 1 & & \\
\hline Age Diversity (D) & $0.75^{* *}$ & $0.55^{*}$ & $0.46^{*}$ & 1 & \\
\hline Gender Diversity (E) & $0.79^{* *}$ & $0.30^{*}$ & $0.49^{*}$ & $0.52^{*}$ & 1 \\
\hline
\end{tabular}

Note: ${ }^{* *}$ Correlation is significant at the 0.01 level (2-tailed).

${ }^{*}$ Correlation is significant at the 0.05 level (2-tailed).

The results show that work performance has a positive and significant correlation with all the diversity of demographic characteristics (in terms of ethnic diversity, education diversity, age diversity, and gender diversity). The results strongly suggest that this diversity of demographic characteristics is more consistent and correlated with the overall work performance in the Nepalese banking industry.

\subsection{Hypotheses Testing}

The coefficient of correlation between ethnic diversity and work performance is 0.72 and is significant at a level of significance of 1 percent (i.e. $\mathrm{r}=0.72, \mathrm{p}<0.01$ ). It supports $\mathrm{H} 1$ as a result. The result indicates that the Nepalese banking industry has a substantial and positive relationship between ethnic diversity and work performance. Besides, the correlation coefficient between the diversity of education and the performance of employees is 0.81 and is significant at a 1 percent significance level ( i.e. $\mathrm{r}=0.81, \mathrm{p}<0.01$ ). It supports $\mathrm{H} 2$ as a result. The result shows that the Nepalese banking industry has a significant and positive relationship between educational diversity 
and work performance.

In addition, the correlation coefficient is 0.75 between age diversity and work performance and is significant at a significance level of 1 percent (i.e. $r=0.75, p<0.01$ ). It supports $\mathrm{H} 3$ as a result. The result suggests that in the Nepalese banking industry, there is a strong and positive relationship between age diversity and work performance.

Finally, the coefficient of correlation between gender diversity and work performance is 0.79 and is significant at a significance level of 1 percent (i.e. $r=0.79, \mathrm{p}<0.01$ ). It supports $\mathrm{H} 4$ as a result. The outcome suggests that the Nepalese banking industry has a substantial and positive relationship between gender diversity and work performance.

Table 8: Summary of Hypotheses Results

\begin{tabular}{|ll|c|}
\hline Hypothesis & Decision \\
\hline H1: & $\begin{array}{l}\text { A strong and positive relationship exists between ethnic diversity and work } \\
\text { performance. }\end{array}$ & Accepted \\
\hline H2: & $\begin{array}{l}\text { A strong and positive relationship exists between education diversity and work } \\
\text { performance. }\end{array}$ & Accepted \\
\hline H3: & A strong and positive relationship exists between age diversity and work performance. & Accepted \\
\hline H4: & $\begin{array}{l}\text { A strong and positive relationship exists between gender diversity and work } \\
\text { performance. }\end{array}$ & Accepted \\
\hline
\end{tabular}

\section{Discussion and Conclusion}

The present study established the relationship between the diversity of demographic characteristics and the performance of employees in the Nepalese banking industry. In terms of ethnicity, the study found that Nepal's banking industry has a diverse workforce. The results indicate that there is a significant relationship between ethnic diversity and the performance of employees. Therefore, the findings of Weiliang et al. (2011) and Early and Mosakowski (2000) are consistent with the results of this study. Most of the workers believe that they cooperate well with peers of various ethnic backgrounds. This suggests that, regardless of the language differences, having workers from different ethnicities does not generate conflict. Likewise, in terms of education, there is a diverse workforce in Nepal's banking industry.

The results indicate that there is a significant relationship between ethnic diversity and the performance of employees. Benschop (2001), Daniel (2009), Kyalo and Gachunga (2015), and Kumar and Suresh (2018) are consistent with the results of this study. The findings indicate that in terms of educational background, the banking industry supports diversity in its workforce composition, and this diversity does not promote conflict between workers but increases their performance as employees come into the organization bringing their various skills and experiences with them.

In addition, this research also confirms that a substantial positive relationship exists between age diversity and work performance. The results of Williams \& O'Reilly III (1998) and Wegge et al. (2008) are consistent with this study's findings. The study shows that workers feel relaxed working with either older or younger staff of different ages as their performance increases. Finally, the results reveal that there is a strong positive relationship between gender diversity and work performance. The issue raised by McMillan-Capehart (2003) and Kochan et al. (2003) is confirmed by this study. A major gender equity relationship would suggest that employees would prefer to work with the opposite sex as long as they can do their tasks efficiently.

\section{References}

Adler, N. (1986). Cultural synergy: Managing the impact of cultural diversity. The 1986 annual: Developing Human Resources, 229-238.

Ashkanasy, N. M., Hartel, C. E. J., \& Dass, C. S. (2002). Diversity and emotion: The new frontiers in organizational behavior research. Journal of Management, 28, 307-338.

Benschop, Y. (2001). Pride, prejudice and performance: Relations between HRM, diversity and performance. International Journal of Human Resource Management, 12, 1166-1181.

Boeker, W. (1997). Executive migration and strategic change: the effect of top manager movement on productmarket entry. Administrative Science Quarterly, 42(2), 213-237.

Brown, S. (2008). Diversity in the workplace: A study of gender, race, age and salary level. Academy of Management Journal, 44(3), 533-545.

Choi, J. (2007). Group composition and employee creative behavior in a Korean electronics company: Distinct effects of relational demography and group diversity. Journal of Occupational and Organizational Psychology, 80(2), 213-234.

Daniel, J.S. (2009). Highlights of the UNESCO Global Forum on Rankings and Accountability: Uses and Misuses, closing presentation, Paris.

Deluca, J.M., \& McDowell, R.N. (1992). Managing diversity: a strategic 'grass-roots' approach. In Jackson, S.E. (Ed.), Diversity in the Workplace: Human Resources Initiatives, Society for Industrial and Organisational 
Psychology - The Professional Practice Series. Guildford Press, New York, NY.

Early, P., \& Mosakowski, E. (2000). Creating Hybrid Team Culture: An Empirical Test of Transnational Team Functioning. Academy of Management Journal, 43(1), 26-49.

Emiko, M., \& Eunmi, C. (2009). Diversity management and the effects on employees' organizational commitment: Evidence from Japan and Korea. Journal of World Business, 44, 31-40.

Erasmus, L. (2007). The management of workforce diversity and the implications for leadership at financial asset services. University of Johannesburg, South Africa.

Erhardt, N.L. (2003). Diversity in the boardroom: gender, ethnicity and firm performance. Graduate School-New Brunswick Rutgers, the State University of New Jersey, USA.

Fernandez, J. P. (1993). The diversity advantage. New York: Lexington Books.

Glaeser, E.L., Scheinkman, J.A., \& Shleifer, A (1995). Economic growth in a cross-section of cities. Journal of Monetary Economics, 36,117-43.

Harrison, D., Price, K., \& Bell, M. (1998). Beyond relational demography: time and the effects of surface- and deep-level diversity on work group cohesion. Academy of Management Journal, 41(1), 96-108.

Jackson, S. E., \& Alvarez, E. B. (1992). Working through diversity as a strategic imperative. In S. E. Jackson (Ed.). Diversity in the workplace: Human resources initiatives, 13-35. New York: Guilford Press.

Jackson, S.E., May, K.E., \& Whitney, K. (1995). Understanding the dynamics of diversity in decision-making teams. In Guzzo, R. Salas, E. and Associates (Eds), Team Effectiveness in Decision Making in Organizations, Jossey-Bass, San Francisco, CA, pp. 204-61.

Jehn, K., Northcraft, G.B., \& Neale, M.A. (1999). Why differences make a difference: A field study of diversity, conflict and performance in workgroups. Administrative Science Quarterly 44(4), 741-763.

Joshi, A. (2006). The influence of organizational demography on the external networking behavior of teams. Academy of Management Review, 31(3), 583-595.

Kilduff, M., Angelmar, R., \& Mehra, A. (2000). Top management-team diversity and firm performance: Examining the role of cognitions. Organization Science, 11, 21-34.

Kochan, T., Bezrukova, k., Ely, R., Jackson, S., Joshi, A., Jehn, K., et al. (2003). The effects of diversity on business performance: Report of the diversity research network. Human Resource Management, 42(1), 3-21.

Kumar, D, \& Suresh, B.H. (2018). Workforce diversity and its impact on employee performance. International Journal of Management Studies, V, Issue-4(1), 48-53.

Kyalo, J., \& Gachunga, H. (2015). Effects diversity in workplace on employee performance in the banking industry in Kenya. The Strategic Journal of Business and Change Management, 2(53), 145-181.

McMillan-Capehart, A. (2003). Cultural diversity's impact on firm performance: The moderating influence of diversity initiatives and socialization tactics. Unpublished doctoral dissertation, Louisiana Tech University, USA.

Milliken, F, \& Martins, L. (1996). Searching for common threads: understanding the multiple effects of diversity in organizational groups. Academy of Management Review, 21(2), 402-434.

Morrison, A.M. (1992). The new leaders: Guidelines on leadership diversity in America. Jossey- Bass Publishers, San Francisco, CA.

Omankhanlen, A., \& Ogaga-oghene, J. (2011). The impact of workforce diversity on organizational effectiveness: a study of a Nigerian bank. Annals of the University of Petroşani, Economics, 11(3), 93-110.

Østergaard, C.R., Timmermans, B., \& Kristinsson, K. (2011). Does a different view create something new? The effect of employee diversity on innovation. Research Policy, 40(3), 500-509.

Pelled, L. (1996). Demographic diversity, conflict, and work group outcomes: An intervening process theory. Organization Science, 7, 615-631.

Rasul, I., \& Rogger, D. (2015). The impact of ethnic diversity in bureaucracies: Evidence from the Nigerian civil service. American Economic Review 105(5), 457-461.

Rosen, B., \& Lovelace, K. (1991). Piecing together the diversity puzzle. HR Magazine, 36(9), 78-84.

Rue, L., \& Byars, L. (1993). Supervision: Key link to productivity. (4th ed.). Chicago: Irwin.

Shaw, J.B., \& Barrett-Power, E. (1998). The effects of diversity on small work group processes and performance. Human Relations, 51(10), 1307-25.

Shrestha, P. (2018). Service quality and customer satisfaction: Evidence of Nepalese banks. NCC Journal, 3(1), 121-133. https://doi.org/10.3126/nccj.v3i1.20254

Shrestha, P. (2019). Banking customer attitudes toward ATM service in Nepal. International Journal of Advances in Scientific Research and Engineering, 5(12), 88-93. DOI: 10.31695/IJASRE.2019.33652

Social Inclusion Action Group (SIAG) (2008). Workforce diversity in international agencies in Nepal. Social Inclusion Action Group, Nepal.

Watson, W., Johnson, L, \& Merritt, D. (1998). Team orientation, self-orientation, and diversity in task groups: their connection to team performance over time. Group \& Organization Management, 23(2), 161-189.

Wegge, J., Roth, C., Kanfer, R., Neubach, B., \& Schmidt, K.-H. (2008). Age and gender diversity as determinants 
of performance and health in a public organization: The role of task complexity and group size. Journal of Applied Psychology, 93, 1301-1313.

Weiliang, E., Mun, L., Fong, T., \& Yuan, Y. (2011). The effects of workforce diversity towards the employee performance in an organization. University Tunku Abdul Rahman, Malaysia.

Williams, K., \& O'Reilly III, C. (1998). A review of 40 years of research. Research in Organizational Behavior, 20, $77-140$. 